\title{
Intestinal mucosa in the Zollinger-Ellison syndrome
}

\author{
J. A. PARRISH AND D. C. RAWLINS \\ From the Department of Medicine, St. Bartholomew's Hospital, London, \\ and Barnet General Hospital, Herts.
}

\begin{abstract}
EDITORIAL SYNOPSIS The gross hypersecretion of acid in the Zollinger-Ellison syndrome is shown to cause oedema, haemorrhages, and increased goblet cell formation in the duodenum in addition to the atypically sited duodenal ulcers.
\end{abstract}

Zollinger and Ellison (1955) showed that the intestine in patients with islet cell tumour of the pancreas was liable to ulcerate at sites typical and atypical of 'peptic' ulcer. These ulcers have been described histologically after resection as being similar to the commonly seen peptic ulcer but reports as to the state of the mucosa between the ulcers or elsewhere in the intestine are few.

We have recently had the opportunity of studying the mucosal morphology of a patient with the Zollinger-Ellison syndrome by means of specimens obtained during small bowel biopsy. The appearances of the pre-ulcerative state of the mucosa and the variability of the abnormalities in different specimens made us feel that these were worthy of record.

\section{CASE HISTORY}

E.W., a white man, aged 37 years, in June 1962 began to have diarrhoea two to three times daily which persisted until January 1963 when he developed abdominal pain, vomiting, and loss of weight. In March 1963 he was admitted to another hospital with jejunal perforation. The mucosa showed evidence of oedema and infiltration with polymorphs, eosinophils, lymphocytes, and other inflammatory cells. Later he was admitted to Barnet Hospital for investigation of anaemia, steatorrhoea, and continued loss of weight.

INVEStigations Haemoglobin was $63 \%$, E.S.R. $33 \mathrm{~mm}$. in the first hour (Westergren), serum albumin 3.05 g., serum globulin $1.6 \mathrm{~g}$., calcium $8.6 \mathrm{mg} . \%$, serum $\mathbf{B}_{12}$ $335 \mu \mu \mathrm{g}$. (normal range 140-900 $\mu \mu \mathrm{g}$.), serum folate $3.2 \mathrm{~m} \mu \mathrm{g}$. (normal range 6-21 $\mathrm{m} \mu \mathrm{g}$.). Faecal fat levels were $83 \mathrm{~g}$. and $64 \mathrm{~g}$. per 72 hours on two separate occasions. The 24-hour gastric aspiration volume was $6,000 \mathrm{ml}$., containing $685 \mathrm{mEq}$. of free $\mathrm{HCl}$.

Serial radiographs of the upper gastro-intestinal tract showed some dilatation of the duodenum and jejunum and a coarse mucosal pattern.

SMALL BOWEL BIOPSY (February 1964) The instrument used was an hydraulically operated biopsy capsule devised by Bolt and French (Bolt, French, and Pollard, 1962; Parrish, 1962). The capsule was passed to the ligament of Treitz and specimens taken from three different sites (Fig. 1), the first at the ligament, the second in the third part of the duodenum, and the third in the second part of the duodenum. During intubation and before biopsy the proximal end of the plastic tubing was not clamped off and throughout the procedure there was a copious flow of strongly acid fluid from this tube even when the capsule head was at the duodeno-jejunal flexure. It was clear also that the volume of fluid in the duodenum was causing considerable distension because when suction was applied immediately before operating the knife, 100 to $200 \mathrm{ml}$. of acid, pale green fluid was aspirated on each occasion before the mucosa could be brought against the capsule aperture. This is in contradistinction to the normal where 0 to $5 \mathrm{ml}$. is the expected finding.

In March 1964 the patient had an exploratory laparo-

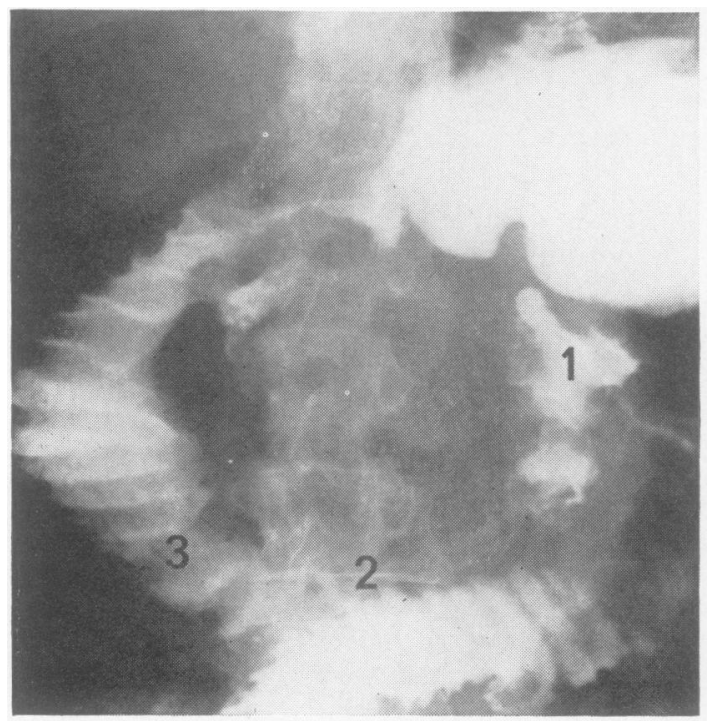

FIG. 1. Radiograph showing sites of biopsy and coarse mucosal pattern. 
tomy and partial pancreatectomy. Although no tumour could be seen at operation, histological examination of the tissue removed revealed the presence of an islet cell adenoma. Gastric aspiration for 24 hours immediately following operation gave a total volume of $750 \mathrm{ml}$. with no free $\mathbf{H C l}$. Four weeks post-operatively the faecal fat output was $32 \mathrm{~g}$. in 72 hours, but after eight weeks had fallen to normal levels of $14 \mathrm{~g}$. in 72 hours.

\section{DISSECTING MICROSCOPIC APPEARANCES OF THE MUCOSA (FIGS. 2, 4, 6)}

The specimens after aspiration were transferred to $10 \%$ formol saline and examined in this medium and photographed.

VILLI The three specimens showed varying degrees of villous abnormality. In specimen 1 there was some loss of villous height similar to the appearance of 'partial villous atrophy' seen in adult coeliac disease. Specimen 2 could be considered of normal leaf-like appearance but in specimen 3 there was an area without obvious villi, 'subtotal villous atrophy'.

EPITHELIAL SURFACE In specimen 1 there was marked oedema which gave rise to a white, glazed appearance and it was possible to make out the outline of individual cells. The degree of haemorrhage seen through the epithelium was notable in this specimen and was greater than that normally seen as a result of suction. The suction pressure exerted in obtaining these specimens was no greater than that usually applied $(60 \mathrm{~mm}$. $\mathrm{Hg})$, although as mentioned above, it took longer before it was possible to apply it.

\section{HISTOLOGICAL APPEARANCES (FIGS. 3, 5, 7)}

The principal features are those of an increase in the number of goblet cells over that normally seen at this level of the gut; cellular infiltration is relatively slight but of the cells that are present plasma cells and lymphocytes predominate and there are in addition some eosinophils and polymorphonuclears; oedema is apparent in the submucosa of all specimens and haemorrhage into the submucosa of specimens 1 and 3.

\section{DISCUSSION}

The mucosa in this patient at the time of biopsy appeared to be in a pre-ulcerative state being both markedly oedematous and also haemorrhagic. Although the haemorrhage noted in this case was probably the result of suction at biopsy, it does suggest that the mucosa is more liable to haemorrhage than normal mucosa under similar conditions.

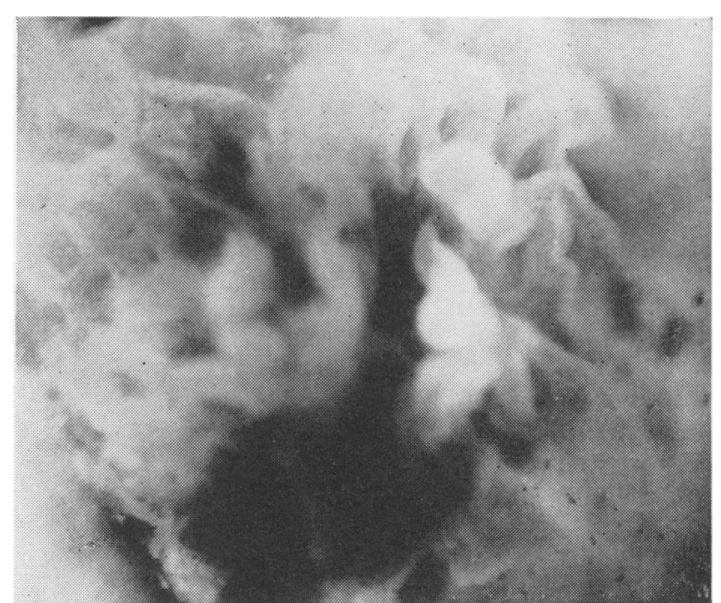

FIG. 2. Biopsy specimen 1 at the duodeno-jejunal junction showing the general appearance of partial villous atrophy and glazed appearance of mucosa due to oedema. Individual cell outlines can be made out. $\times 40$.

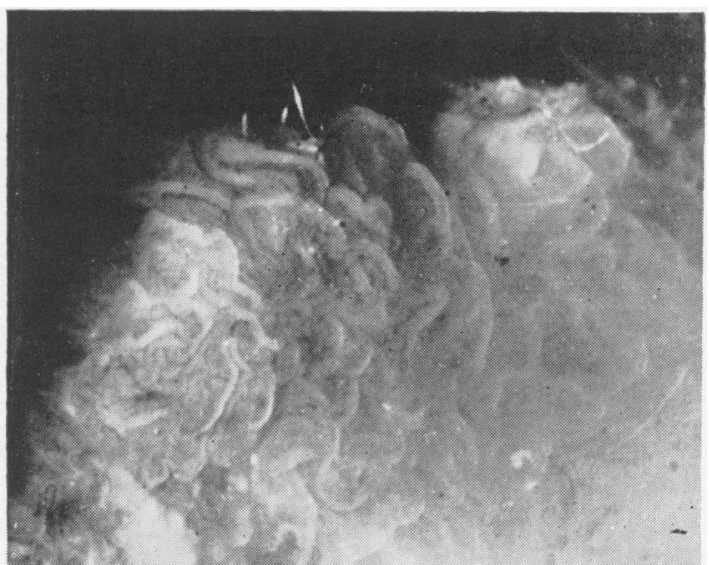

FIG. 4. Biopsy specimen 2, third part of the duodenum showing a normal leaf-like villous pattern. The villous capillary network is clear. $\times 24$.

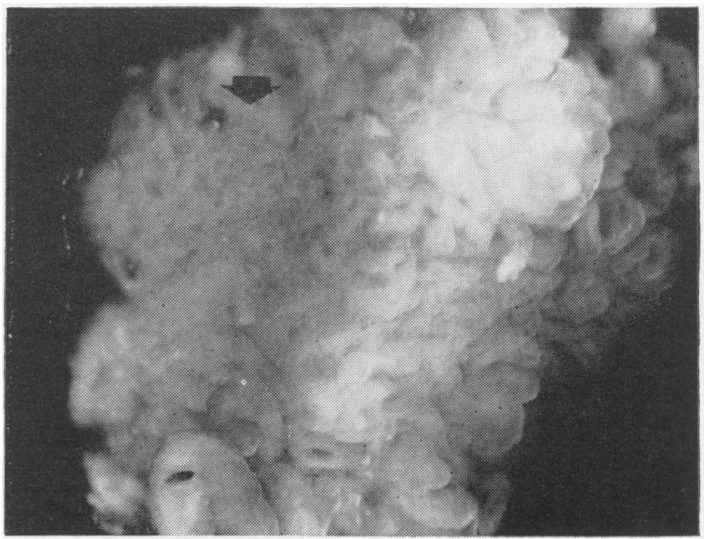

FIG. 6. Biopsy specimen 3, second part of the duodenum, showing an area at top and centre left where there are no villi (subtotal villous atrophy) and the mouths of the crypts can be seen. Elsewhere villi appear ridged and in folds. $\times 25$. 


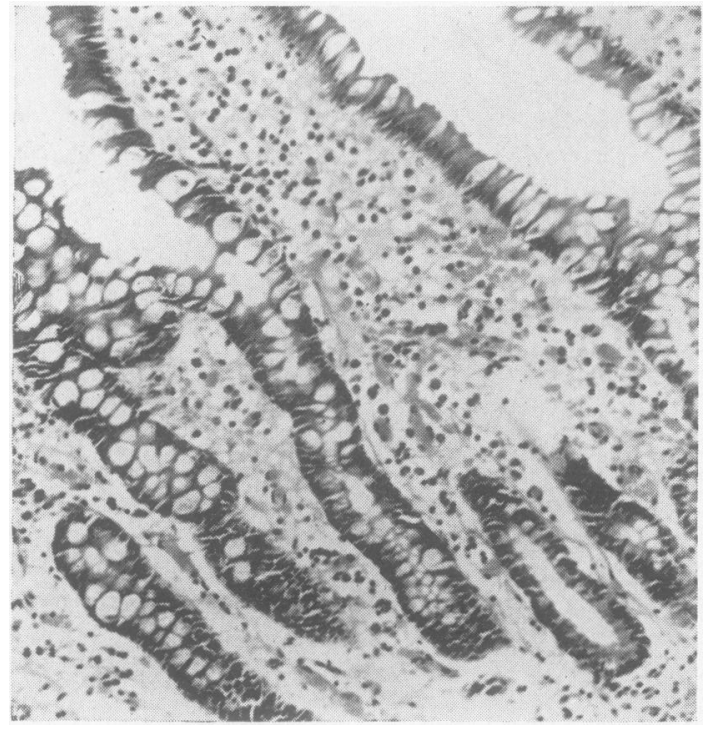

FIG. 3. Biopsy specimen 1. Duodeno-jejunal junction. Section shows a marked increase in the number of goblet cells over that normally seen at this level. (Haematoxylin and eosin $\times 95$.)

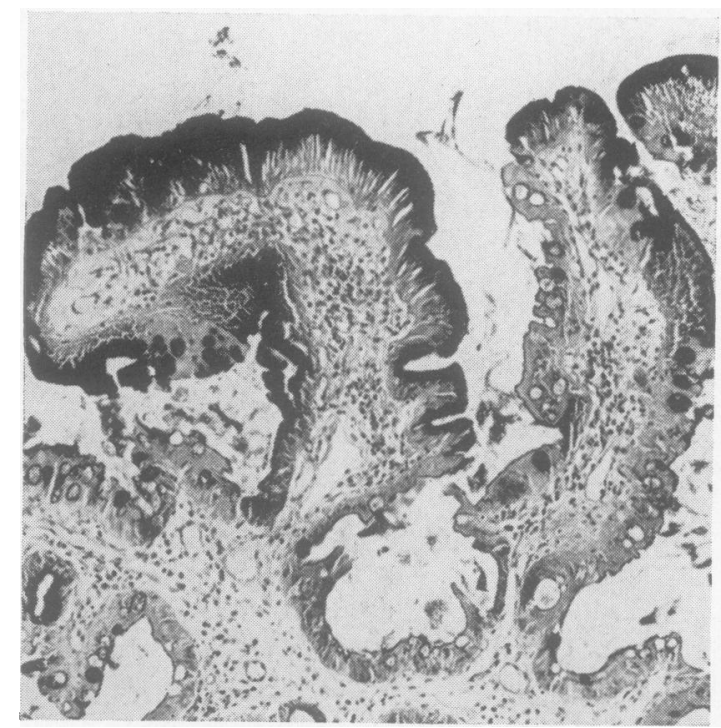

FIG. 5. Biopsy specimen 2, third part of the duodenum. Section shows the tips of three villi with an increased number of goblet cells and mucin-producing 'gastric' cells. (P.A.S. $\times$ 95.)

In support of this supposition Summerskill (1959) reported a case in which there were several areas of haemorrhage in association with five chronic ulcers.
In his case there were elongated villi and numerous inflammatory cells which had infiltrated the whole thickness of the intestine. It is possible that the infiltration in Summerskill's case occurred as a result of the ulceration rather than being an associated cause of it. In our patient there was no marked infiltration, and similar observations were made by James (1964).

Villous length appeared less than normal in a patchy distribution, in specimen 3 there was one area devoid of villi, possibly the site of potential ulceration, and such flattening of the mucosa has been noted experimentally in dogs by Anderson (1962), while in specimen 2 villi appeared normal.

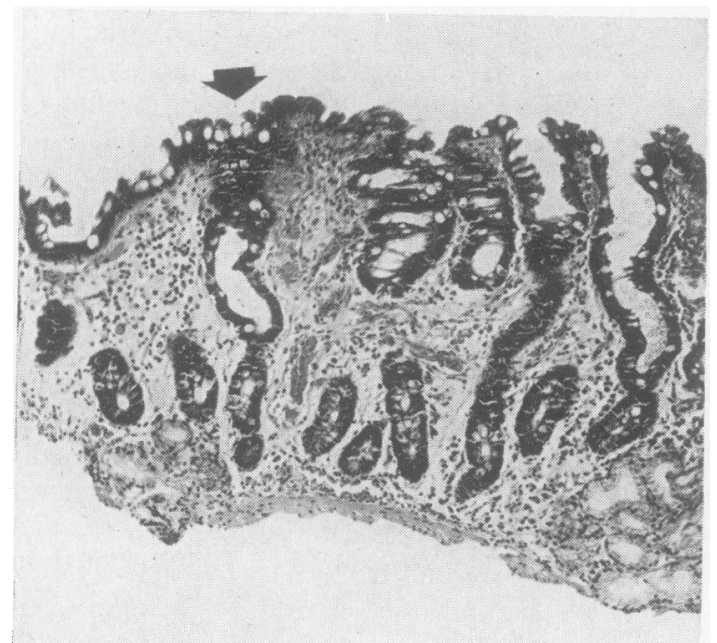

FIG. 7. Biopsy specimen 3, second part of the duodenum. Section shows oedema, slight cellular infiltration, and slight haemorrhage of the submucosa. Goblet cells are moderately increased and villi are short or absent. The area arrowed corresponds with the flat area in Figure 6. (Haematoxylin and eosin $\times 50$ ).

James (1964) found an increase in the amount of mucin produced in the second part of the duodenum in a case of the Zollinger-Ellison syndrome and our case has demonstrated a similar change as far as the duodeno-jejunal flexure.

In these cases the exposure of the mucosa to enzymes is increased in respect of pepsin but decreased in respect of the pancreatic enzymes which cannot act at such a low $p \mathrm{H}$. It is also probable that this inactivation of pancreatic enzymes is as likely to be the cause of the steatorrhoea (Maynard and Point, 1958) as is the epithelial cellular damage caused by the acidity of the luminal contents. 
The mucosal morphology of the duodenum in a patient with an islet cell tumour of the pancreas is described from a study of mucosal specimens obtained by small bowel biopsy. Both dissecting and light microscopy show evidence of oedema, haemorrhage, and increased goblet cell formation. The relationship of this state of the mucosa to that of actual ulceration is briefly discussed, and the value of obtaining more than one mucosal specimen is demonstrated.

We would like to thank Dr. G. R. Royston for permission to publish details of this patient under his care, also Mr. P. Crocker and Miss A. Butler, of the Department of Pathology, St. Bartholomew's Hospital, for the photographs and histological sections respectively.
Anderson, C. M. (1962). Discussion. In Intestinal Biopsy (Ciba Foundation Study Group No. 14), edited by G. E. W. Wolstenholme and M. P. Cameron, pp. 19-20. Churchill, London.

Bolt, R. J., French, A. B., and Pollard, H. M. (1962). A simplified multiple-retrieving small-bowel biopsy tube. Amer. J. dig. Dis., 7, 773-778.

James, A. H. (1964). Gastric epithelium in the duodenum. Gut, 5, 285-294.

Maynard, E. P., III, and Point, W. W. (1958). Steatorrhea associated with ulcerogenic tumor of the pancreas. Amer. J. Med., 25, 456-459.

Parrish, J. A. (1962). Small bowel biopsy. St. Bart. Hosp. J., 66, 199-202.

Summerskill, W. H. J. (1959). Malabsorption and jejunal ulceration due to gastric hypersecretion with pancreatic islet-cell hyperplasia. Lancet, 1, 120-123.

Zollinger, R. M., and Ellison, E. H. (1955). Primary peptic ulcerations of the jejunum associated with islet cell tumors of the pancreas. Ann. Surg., 142, 709-728. 